\title{
Market Value, Book Value and Earnings: Is Bank Efficiency A Missing Link
}

\author{
Mehreen Ishtiaq, Naeemullah \\ Foundation University Rawalpindi Campus $\backslash$ \\ Assistant Professor Foundation University Rawalpindi Campus
}

\begin{abstract}
The purpose of this study is to examine that the earnings components and banking efficiency are relevant to the market value of the banks or not. Testing the relationship we used DEA for the banking efficiency and regression model is estimated because it is panel study we used Common effect, fixed effect and random effect on the Pakistani banks included in this study. Frequency of data is yearly and is started from year 2008 to year 2012. Findings of our study gives number of directions, first of allin analysis it is found that the components of earnings are related to market value of the banks, secondly cost efficiency adds the additional information to the market. It can be concluded that earning's components and operational efficiency both explain the market value further these results suggest that stock prices reflect both the information generated through market as well from the accounting System. This study helps to explain the market value of the shares through banking efficiency and accounting information. According to our best knowledge this study is unique among the studies because it is the first study in the emerging economy which explains the market value through earnings components and efficiency of the banks.
\end{abstract}

Key Words: Efficiency, Earnings Components, Market Value, Book Value, Panel study, Banks

\section{Introduction:}

In the world, emerging economies provided an opportunity to analyze the effect of regulation and liberalization on the performance of banking efficiency. As both these measures i.e. liberalization and regulations have the effect on the performance of banking sector especially in emerging economies. With respect to Pakistan as it is included in the emerging economies, building their banks on market based institutions. Central bank which is state bank of Pakistan, introduced number of regulatory measures for example, export promotion, price stability and other stability measures of State Bank of Pakistan affect the performance of the banking sector. In Emerging economy as well as in the developed world banks are facing huge level of competition, due to this banks having lot of capacity to expand their lines of business and becomes more market oriented. Complexity in the banking sector increases when they move from traditional way of business to become more market based and providing non-banking product and services such as insurance and asset management. Therefore such big changes force the banks to rely on intangibles assets. According to Ang and Clark (1997), it is frequently observed that there is no more equivalency between banks book and market value.

There are different ways to evaluate the performance of the banks i.e. accountants take book to evaluate the performance whereas economist analyze the bank performance through their fair value or intrinsic value, but stakeholders are concerned only on market value. As it is mentioned that there is lot of difference between book and market value, and the book value actually do not reflect true picture of the security. Kothari (2001) said that if there is difference among fair value ( intrinsic value), market value and current stock prices it produced signal to invest in security for expect return. If these securities will not provide sufficient return the investor is no more willing to hold it, then ultimately the company may face short of fund to finance their growing project. Investing in security whether it will provide sufficient return or not we have numbers of indicators, the basic and vital indicator is earnings. Researchers have tested number of models to find the relationship between earnings and firm fundamentals and market values.

According to Kothari (2001) it is observed that prices of the stocks generally do not reflect the true prices or do not reflect the variation in income or loss. Which means only accounting information are not sufficient to explain the current stock prices. Number of previously studies support the fact that only book value of banks are insufficient for example, according to Liedtka (2002) as well as another famous researcher Liang an Yao (2005) found in their study that only accounting information are insufficient and stock prices are better explained by the combination of economic information as well as the financial information.

In this arena where everything is facing lot of competition, banking sector is the one who is facing lot of competition, so to survive and succeed in the banking sector banks have to produce maximum level of outputs from the given level of inputs. According to Adenso-Diaz and Gascon (1997) banks are relative efficient when they are producing more output under the given levels of output from their competitors. Berger (2007) 
found that there is lot of literature on the banking efficiency but did not found any relationship about banking efficiency and stock performance. Only fewer studies which discussed the issue of banking efficiency and stock performance for example Lim (1998) and Fiordelisi (2007) analyzed the banking efficiency and stock performance.

Our study attempts to examine whether bank market value is affected by the cost minimization or not. The scope of our study is also to know the relationship between market value and income components. Our study is very important because it evaluates the earlier studies which describes the relationship between stock performance and banking efficiency and according to our best knowledge this is the first study on emerging economies especially with respect to Pakistani context. This study also helps the policy makers to assess the banking policies because it affects the banks performance.

The sequence of paper is adopted as, section 2 covers the literature review followed by the data and methodology which is in section 3. Results and discussion are in section 4 and finally conclusion is in the section 5 .

\section{Literature Review:}

In this paper we examine whether there is any difference between book value and market value of shareholders equity when the participants of market have the information of banking efficiency that banking efficiency produce better profit. In this type of study we are concerned with two types of literature namely; market based accounting literature and banking efficiency literature. First we discuss the market based accounting literature or value relevance literature.

\subsection{The Value Relevance Literature}

According to Kothari (2001) relevant information means the information which carrying the financial statements impact the capital markets, on this issue number of studies have been dome and is an emerging area of research. Information is considered relevant if the movements in stock prices are associated with released information. According to Collins et al. (1997) as well as the another famous researcher Dontoh et al. (2004) said when we regress stock prices or stock returns on accounting information it gives us adjusted $R^{2}$, this adjusted $R^{2}$ used for value relevance determination. There are numerous studies available in the literature which discussed that accounting number i.e. earnings gives key information in the context of stock returns. A great attention was started since the work of Ohlson (1995), as he said that determining the equity valuation earnings and book values are the major components. In his paper he used the model which helps to identify the necessary factors which affect the value of the firm. He provided strong theoretical justification for these two variables, he said that book value shows the stock measure and earnings which is flow variable takes increments in the book value. So according to Ohlson both these variables i.e. book value and earnings are very important for equity valuation.

According to Giner and Reverte (1999) and the most famous study of Chen and Wang (2004) said that investors are more concerned about earnings components rather than aggregate earnings. The reason behind this is, though earnings consider better indicator for evaluation but if it loses reliability in the stakeholder mind then they consider earnings components rather than earnings. When Lipe (1986) tested whether earnings' components and earnings provide different results or explain differently. He found interested results those earnings components are providing statistically significant information rather only earnings components. This also supported by the researcher, e.g. Ohlson and Penman in 1992 when they found in their study that shares performance is different with earnings components in the short run while in the long run security returns reacts same over earnings and earnings components.

According to Dontoh et al. (2007) the information which is producing by the company through their published statements are not more valid to assess the market value of the firms especially those which are highly technology based. Quinn et al., (1996) confirmed in his seminal paper that information provided by the financial statements is not more relevant because of new economic era which is knowledge based economy. Kane and Unal (1990) found in their study that book value misleads the shareholder's equity in terms of market value because un-booked capital. As Kane and Unalsaid that unbooked capital is always present when firms net worth differs from the economic value.

Stakeholders are conscious about market and book values because they want to invest in those securities which give maximum returns. Though book value and market value affect the market return but according to Baele et al. (2007) return and diversification affect the security return. He also found in his paper that return will be slightly higher if there is higher level of diversification present in the portfolio.

The second part of the literature which is related to the bank efficiency and valuation of the security is discussed here. Efficiency or banking efficiency is considered as an intangible asset for banking sector which measures the performance of the banks, can be calculated using information collected from publicly or through updated techniques which can be either parametric or nonparametric. 


\subsection{Impact of bank efficiency on the bankvaluation}

The definition of efficiencyis different with respect to different authors for exampleaccording to Mc Williams and Smart (1993) efficiency is seen in the industrial organizations as well as in the strategic management literature. It involves number of factors such as market share, cost control, innovation and management skill that determines the firm performance and its stability. According to Cebenoyan (2003) Efficiency is the relationship between ends and means, and it is suggested that it is the extent to which they are matched. Goddard et al. (2007) said that banks are focusing on, to identify the ways which are beneficial to decrease cost. Cost can be decreased either by product mix or forming the optimal firm size or by maximizing operational and productive efficiency.

Productive or operational efficiency has two components one is the technical efficiency and other is the allocative efficiency. Achieving technical efficiency means under the given target of output one have to produce that output with minimum cost of inputs or it can be said that achieving maximum level of outputs under the given level of inputs. On the other hand allocative efficiency means ability of using the inputs in such optimal proportions with respect to their respective prices which give minimum cost. Allocative Efficiency (AE) also defined as mixing the inputs in such a way that produced the output at minimum level of cost.

Measuring efficiency is an important issue but this issued resolved by Davidson (1997) when he used in his paper a well-known cost income ratio. The basic theme behind this ratio is that it is intuitively acceptable and it is often said the efficiency ratio. As the valuable contribution by the Cocheo (2000) used this in his paper as an important bench mark. No doubt this ratio is meaning full but in literature evidence is presented that there is significant relationship between the security return and cost income ratio under sample of banks. Osborne (1995) found that there is no relationship between cost income ratio and return on the security. Fiordelisi (2007) creates a new measure of efficiency which he names it as shareholder value efficiency. According to Fiordelisi the banks which produced more economic value added are efficient banks rather those banks which do not produce Economic Value Added (EVA).

\section{Data and Methodology:}

In this study we have taken seventeen banks over the five year data starting from year 2008 to year 2012. The scope of this study is see the efficiency of banks on the basis of technical efficiency, cost efficiency and also to investigate whether technical efficiency explain the market value of the firm or not. In this paper we also analyzed the relationship between market value of the firm and information which are disclosed by financial statements and economic information. In our study we adopted the model which was given by Ohlson's (1995) in his paper he describes the relationship between market value of the firm and financial and nonfinancial information. Later on numerous studies also adopted this model in their paper for example Biddle et al. in year 1997, Myers in year 1999, Dochow et al. in year 1999, Trueman et al. in year 2000 andCallen and Morel in year 2001. On the basis of lot of evidence available in the literature about this model we also used this model in our analysis to find the relationship between return of the security and information (financial or nonfinancial). In this paper particularly we adopted the methodology which use by the Trueman's et al. (2001) which is the extension of methodology used by Ohlson's in 1995. The model is given below $M V_{j t}=\beta_{0}+\beta_{1} B V_{j t}+\beta_{2} O I_{j t}+\beta_{3} O T H E R_{J t}+\beta_{4} O E X P_{j t}+\beta_{5} E F F_{j t}+\varepsilon_{j t}$ In the above equation $M V_{j t}$ is the market value of bank $\mathrm{J}$ and here $\mathrm{t}$ subscript stands for time period for each bank. $\beta_{0}$ is our constant or intercept slop, $\beta_{1}$ is slope coefficient of book value of equity, $B V_{j t}$ is the book value of common stock of bank $\mathrm{J}$ at time period $\mathrm{t}, \beta_{2}$ is coefficient of operating income, $O I_{j t}$ is the operating income of banks $\mathrm{j}$ at the end of time period t. $\beta_{3}$ is the coefficient of expenses in which interest and noninterest expenses are not included, $O T H E R_{J t}$ this is the expenses except interest and noninterest expenses banks $\mathrm{J}$ and time period t, $\beta_{4}$ is the coefficient of operating expenses, whereas $O E X P_{j t}$ is the operating expenses of banks which are directly related to the interest expenses of banks $\mathrm{j}$ normally it is at the end of the accounting period, $\beta_{5}$ is the coefficient of efficiency which is the scale efficiency, $E F F_{j t}$ is the cost efficiency of each banks $\mathrm{j}$, showing efficiency at the end of the time period and $\varepsilon_{j t}$ is the error term or the random term of the model.

\section{Results and Discussions:}

We did comprehensive analysis on the efficiency of banks, as well as the earning components and market value of the shares of banks. Cost efficiency of banks is calculated through the Data Envelopment Analysis (DEA). Table 1 shows the efficiency of banks included in this study. 
Market Value, Book Value And Earnings: Is Bank Efficiency A Missing Link

Table 1. Mean values of variables used for efficiency

\begin{tabular}{|l|l|l|l|l|l|l|}
\hline Year & CRSTE & VRSTE & Scale & TE & AE & CE \\
\hline $\mathbf{2 0 0 8}$ & 0.745 & 0.826 & 0.911 & 0.967 & 0.964 & 0.934 \\
\hline $\mathbf{2 0 0 9}$ & 0.691 & 0.814 & 0.860 & 0.908 & 0.867 & 0.788 \\
\hline $\mathbf{2 0 1 0}$ & 0.242 & 0.365 & 0.611 & 0.957 & 0.959 & 0.920 \\
\hline $\mathbf{2 0 1 1}$ & 0.195 & 0.306 & 0.637 & 0.863 & 0.888 & 0.772 \\
\hline $\mathbf{2 0 1 2}$ & 0.815 & 0.861 & 0.947 & 0.975 & 0.860 & 0.839 \\
\hline Average & 0.538 & 0.634 & 0.793 & 0.934 & 0.908 & 0.851 \\
\hline
\end{tabular}

In the above table, CRSTE stands for constant return to scale, VRSTE stands for variable return to scale, Scale means scale efficiency, and TE stands for technical efficiency, AE stands for allocating efficiency, CE stands for Cost efficiency. In the above table efficiency is calculated especially cost efficiency which is the last column of the above table. Cost efficiency of Pakistani banks from year 2008 to year 2012 is 85 per cent which is the average of cost efficiency of banks but the interval of cost efficiency is from 77 percent to 93 percent. In year 2008 banks are showing 93 percent and in year 2010 banks are showing $92 \%$.

It can be concluded that Pakistani banks will save fifteen percent (15\%) from their total costs if they follow best practice. It means at the same level of outputs Pakistani banks can cut their costs to the extent of $15 \%$. This also means that eighty five percent of the banks inputs are operating at their best efficient level. Under the scale efficiency Pakistani banks seventy nine percent efficient which means on average $21 \%$ improvement is remaining in their inputs. In year 2012 banks are efficiently using their products to the extent of $95 \%$ and only five percent improvement is there.

Table 2: Descriptive Statistics of Variables used in Regression

\begin{tabular}{|l|l|l|l|l|}
\hline Variable & Mean & Std. Dev. & Minimum & Maximum \\
\hline MV & 16.840 & 1.693 & 14.308 & 25.238 \\
\hline BV & 16.889 & 0.980 & 15.370 & 18.598 \\
\hline OI & 17.115 & 1.074 & 14.718 & 18.703 \\
\hline OTHER & 16.500 & 0.966 & 14.292 & 17.960 \\
\hline OEXP & 16.367 & 0.972 & 14.124 & 17.893 \\
\hline EFF & 0.7952 & 0.072 & 1 \\
\hline
\end{tabular}

The above table represents the mean, minimum, maximum and standard deviation of those variables which we included for analysis in our model. The mean value of the market value of the share is 16.480 which are in $\log$ form, and the mean value of book value of share is 16.889 but this is in absolute form. The maximum value of market value of share is 25 and minimum value of share price is 14 which are again in $\log$ form. But the maximum book value of share price is 18 and minimum book value of share price is 15 , book value is measured in absolute terms.

Conclusion can be drawn that prices of shares of Pakistani banks are greater with respect to market value and are less with respect to book value. It is also noticeable that the gap between two requires some other relevant variables which explain the gap between the two. It is also noteworthy that standard deviation of market value of the share price is greater than the standard deviation of the book value of the share price. This is theoretically justified because market value of the share price is greater than the book value of the share price. Normally it is observed that higher the value, higher is standard deviation as well and lower the value brings lower standard deviation. The mean value of efficiency is $79 \%$ which means currently Pakistani banks seventy nine percent of their inputs using efficiently and the interval in which Pakistani banks efficiently using their inputs ranges from 7 percent to hundred percent and the standard deviation of efficiency is 23 percent.

Table 3. Regression Results:

\begin{tabular}{|l|l|l|l|l|}
\hline & Coefficient & Std. Err & t-Statistics & Probability value \\
\hline BV & 0.743 & 0.253 & 2.93 & 0.005 \\
\hline OI & 1.753 & 0.564 & 3.10 & 0.003 \\
\hline OTHER & -0.271 & 0.200 & -1.36 & 0.180 \\
\hline OEXP & -1.181 & 0.475 & -2.48 & 0.016 \\
\hline EFF & 0.713 & 0.310 & 2.30 & 0.025 \\
\hline Constant & 1.504 & -1.68 & 0.098 \\
\hline
\end{tabular}

To know the market value of the banks, our model consists of five explanatory variables namely book value, operating income, other, which is the proxy of expenses other than interest and not interest expenses. Operating expenses which includes the interest and non-interest expenses and last variable is the scale efficiency which is the measure of to check whether banks are producing their output at cost efficient or not. In our model, book value, operating income and cost efficiency have positive significant relationship with market value. As per theory book value coefficient should be positive, our result fulfill the theory sign is positive and also it has significant relationship with market value at the $95 \%$ confidence interval. It is found that Operating income has 
positive coefficient sign and also has significant relationship market value which means operating income can explain the market value of the banks.

The coefficient of cost efficiency is positive and also is signification with market value under the hypothesis that it should affect positively to the market value of the banks. As this hypothesis is accepted under the five percent level of significant. As per theory and our claim, the result of cost efficiency fulfills our criteria. The main finding from this cost efficiency is that it explains the difference between market and book value of the banks. Our results support the conclusion of Beccalli et al., (2006) and another study which was analyzed by Kirkwood and Nahim (2006). This conclusion leads us that cost efficiency brings improvement in banks which is further reflected in banks market value.

According to theory and judgment expenses should have negative affect on the market value of the banks, because when expenses will be higher, ultimately income will be low when income is low it inversely affect the market value of the banks. Fortunately our results comes under this head are according to theory and fulfilled the conditions. As we have used two types of expenses one is the operating expenses and second one is the other expenses which we measured as that, those expenses other than interest expenses. Other expenses and operating expenses both have negative coefficient sign and also operating expenses is significant at the five percent level of significant which means operating expenses affects the market value of the banks substantially, but on the other hand other expenses as per theory negatively affects the market value of the banks but is not significant at the five percent level of significance.

Table 4:Correlation Results:

\begin{tabular}{|l|l|l|l|l|l|l|}
\hline & Lnmv & Equity & Operating Income & OTHER & OEXP \\
\hline Lnmv & 1 & & & & & \\
\hline Equity & 0.8507 & 1 & & & & \\
\hline Operating Income & 0.8088 & 0.4236 & 1 & & & \\
\hline OTHER & 0.7741 & 0.3956 & 0.4370 & 1 & & \\
\hline OEXP & 0.7570 & 0.4750 & 0.4208 & 0.4214 & 1 & \\
\hline Cost Efficiency & 0.2008 & 0.4126 & 0.1869 & 0.1521 & 0.1920 \\
\hline
\end{tabular}

The above table shows the relationship among the avariables, for example market value of the banks and book value of the banks are highly correlated which is $85 \%$ in the same way market value of the banks and operating income are highly correlated which are 0.8088 or $81 \%$. OTHER expenses are 77 percent correlated with market value of the banks and operating expense are 75 percent correlated and cost efficiency is only twenty percent correlated with market value of the banks. All other explanatory variables are also correlated with each other but they are less than 50 percent which is healthy sign because when explanatory variables are correlated with each other with higher than $50 \%$ it is the sign of multicolinearity and our results can be biased. So we can conclude that in our sample all the explanatory variables are less than fifty percent correlated.

\section{Conclusion}

In this study we have developed and tested number of hypothesis about the market value of the firm and earnings components e.g. operating Income, Other expenses and operating expenses. We also seen the effects of book value and cost efficiency on the market value of the firm. This study is very important because it extend the literature with two respects. Normally in the literature it is found that market value of the bank is explain through the aggregate earnings but we did a unique thing and explain the market value through the earnings components rather than earnings. The second contribution in the literature is that we explain the difference between book and market value using the variables of relative cost efficiency of banks which is based on the production theory.

This study is very important because it has unique strengthbecause it evaluates the banking efficiency with respect to shareholders perspective and it also contributes in the banking literature because our study analyzes the relationship between bank's stock performance and cost efficiency. This particular study also helps the shareholders as it advances literature by knowing whether cost efficient banks are creating value for investors or not. Evaluating the relationship between market value of the firm and earnings components we adopted the methodology of Trueman et al. which he adopted in his paper in year 2000 which was also based on Ohlson (1995).

Our study concludes that earnings components have significant relationship with the market value of the banks. Which means earnings components explain the market value of the banks whereas it is also found the cost efficiency which is another performance measure that provides information to explain the market value of the banks. Results of this study also support the conclusion of Dutta and Reichelstein (2005) which also observe that difference between book and market value is the management's unobservable efforts which are ultimately trace out in earnigscomponets rather than aggregate earnings. Market value and cost efficiency has the positive 
relationship which is according to theory and also support the conclusion of Eisenbeis et al. (1999) and Baccalli et al. (2006).

The implication of this study is that it is beneficial for the investor that market value reflects the better indication rather than the book value. It also helps executives that banking efficiency is important for the better market value.

\section{References:}

[1]. Kothari, S. (2001).Capital market research in accounting. Journal of Accounting and Economics, 31,105-231.

[2]. Amir, E., \& Lev, B. (1996).Value-relevance of non-financial information: the wireless Communications industry. Journal of Accounting and Economics, 22, 3-30.

[3]. Ittner, C., \&Larcker, D. (1998).Are non financial measures leading indicators of financialperformance? An analysis of customer satisfaction.Journal of Accounting Research, 36, 1-35.

[4]. Trueman, B., Wong, M., \& Zhang, X. (2000). The eyeballs have it: Searching for the value in internet stocks. Journal of Accounting Research, 38, 137-62.

[5]. Liang, C., \& Yao, M. (2005).The value relevance of financial and nonfinancial informationevidencefrom Taiwan information electronic industry.Review of Quantitative Finance and Accounting, 24, 135-57.

[6]. Adenso-Diaz, B.,\&Gascon, F. (1997).Linking and weighting efficiency estimates with stock performance in banking firms, Wharton School working paper, 97/21.

[7]. Berger, A. (2007). International comparisons of banking efficiency.Financial Markets, Institutions and Instruments, 16, $119-44$.

[8]. iordelisi, F. (2007). Shareholders value and efficiency in European banking.Journal of Banking and Finance, 31, $2151-71$.

[9]. Collins, D., Maydew, E.,\&Weiss, I. (1997).Changes in the value-relevance of earnings and bookvalues over the past forty years.Journal of Accounting and Economics, 24, 39-67.

[10]. Dontoh, A., Radhakrishnan, S., \& Ronen, J. (2004). The declining value-relevance of accountinginformation and non-informationbased trading: an empirical analysis. Contemporary Accounting Research, 21, 795-813.

[11]. Ohlson, J. (1995). Earnings, book values, and dividends in equity valuation. ContemporaryAccounting Research, 11, $661-87$.

[12]. Chen, S., \&Wang, Y. (2004).Evidence from China on the value relevance of operating income vs. below-the-line items.International Journal of Accounting, 39, 339-64.

[13]. Lipe, R. (1986). The information contained in the components of earnings. Journal of Accounting Research, $24,37-68$.

[14]. Quinn, J., Anderson, P.,\&Finkelstein, S. (1996). Leveraging intellect.Academy ofManagement Executive, $10,7-27$.

[15]. Kane, E.J., \& Unal, H. (1990).Modeling structure and temporal variation in the market'svaluation of banking firms.Journal of Finance, 45, 113-36.

[16]. Baele, L., Jonghe, O.,\&Vennet, R. (2007). Does the stock market value bank risk.Journal of Banking and Finance, 31,1999-2032.

[17]. McWilliams, A., \& Smart, D. (1993).Efficiency vs structure-conduct-performance: implicationsfor strategy research and practice. Journal of Management, 19, 63-78.

[18]. Goddard, J., Molyneux, P., Wilson, J., \&Tavakoli, M. (2007). European banking: an overview. Journal of Banking \& Finance, 31, 1911-35. 